\title{
Electrochemistry of $\mathrm{Zr}(\mathrm{IV})$ in molten $\mathrm{LiCl}-\mathrm{KCl}-\mathrm{K}_{2} \mathrm{ZrF}_{6}$ System
}

\author{
Chunyue Li, Wei Han, Mei Li, Wei Wang, Xiaoguang Yang* \\ Key Laboratory of Superlight Materials and Surface Technology, Ministry of Education, College of \\ Material Science and Chemical Engineering, Harbin Engineering University, Harbin 150001, P. R. \\ China \\ *E-mail: yxg1122@163.com
}

doi: $10.20964 / 2018.12 .04$

Received: 10 April 2018 / Accepted: 8 September 2018 / Published: 5 November 2018

\begin{abstract}
The electrochemical behaviors of $\mathrm{Zr}(\mathrm{IV})$ in the molten $\mathrm{LiCl}-\mathrm{KCl}-\mathrm{K}_{2} \mathrm{ZrF}_{6}$ system were investigated on tungsten and copper electrodes at $993 \mathrm{~K}$ respectively. By electrochemical tests including cyclic voltammetry, square wave voltammetry, chronopotentiometry and open circuit chronopotentiometry. $\mathrm{Zr}$ (IV) was reduced to $\mathrm{Zr}(0)$ in two steps with two electrons transfer in each one. The diffusion coefficient of $\mathrm{Zr}$ (IV) was $5.01 \times 10^{-5} \mathrm{~cm}^{2} / \mathrm{s}$ examined by cyclic voltammetry in the molten salts. The electrochemical signal of $\mathrm{Cu}-\mathrm{Zr}$ intermetallic compound was detected at $-1.0 \mathrm{~V}(\mathrm{vs} . \mathrm{Ag} / \mathrm{AgCl}) . \mathrm{Cu}_{5} \mathrm{Zr}$, $\mathrm{Cu}_{51} \mathrm{Zr}_{14}$ and $\mathrm{Cu}_{8} \mathrm{Zr}_{3}$ were obtained by galvanostatic electrolysis at $0.05 \mathrm{~A}$ for $20 \mathrm{~h}$. These intermetallic compounds were characterized by X-ray diffraction analysis (XRD) and scanning electron microscopy with energy dispersive spectrum (SEM-EDS). In this work we provided an efficient way to prepare $\mathrm{Cu}-\mathrm{Zr}$ intermetallic compounds.
\end{abstract}

Keywords: Zirconium, Copper, Electrochemical test, Galvanostatic electrolysis, Intermetallic compounds

\section{FULL TEXT}

(C) 2018 The Authors. Published by ESG (www.electrochemsci.org). This article is an open access article distributed under the terms and conditions of the Creative Commons Attribution license (http://creativecommons.org/licenses/by/4.0/). 